\title{
THE ASSIGNABILITY OF EASEMENTS IN GROSS
}

\author{
Geratd E. WELsh*
}

W HEN we read in a legal textbook a rule of law'stated unequivocally, we are inclined to accept it. However, textbook writers can make mistakes, and courts, by way of dicta, can continue to repeat the mistakes.

Such a mistake has been made and continuously repeated by textbook writers and by the dicta of the courts with respect to the question of the assignability of easements in gross. As a result, much confusion has been introduced into the realm of law dealing with the assignability of easements, and the courts have struggled to create exceptions so as not to follow an alleged rule which should have been renounced and forgotten long ago.

In general, textbook writers and law publications recite the alleged rule in virtually the same form in which it is set forth in American Jurisprudence:

An easement in gross is a mere personal interest in the real estate of another. Subject to some authority to the contrary, the rule followed by the great majority of courts is that an easement in gross is so essentially personal to the grantee that it is not assignable or inheritable and cannot be made so by the terms of the grant.

Such is the type of statement which is generally found in most of the commercial legal publications. ${ }^{2}$

The principal distinction between an easement in gross and an easement appurtenant is that in the first there is not, and in the second there is, a dominant tenement. ${ }^{3}$ The ridiculousness of the alleged rule becomes immediately apparent when it is realized that easements for railroads, public highways, street and interurban railways, pipe lines, and canals, and public service easements of all types, such as power lines and telephone lines, are easements in gross. As a result of this erroneous statement of the law by textbook writers and in early cases, the courts have generally felt duty bound to repeat it by way of dictum, and have then proceeded to go

*Division Attorney, American Telephone and Telegraph Co., Denver, Colorado.

× Vol. I7, "Easements," § Ir.

${ }^{2}$ Jones, Easements $\S 39$ (1938); Thompson, Real Property $\S 34$ I (1939); Amer. \& Eng. Encyclopaedia of Law vol. Io, p. 403 (2d ed., x899); xg Corpus Juris $§ 5$.

3 American Jurisprudence vol. I7, "Easements," $\$$ I2 (I938); 9x Corpus Juris $\S 5$. 
to great lengths to find the easement involved in the particular case to be an easement appurtenant, and, if unable to do so, have proceeded to create an exception or to find a reason for not following the alleged rule.

The origin of the so-called rule was an early English case, Ackroyd v. Smith, ${ }^{4}$ which held that the right, granted in a conveyance of land to the grantees of the premises and all persons having occasion to resort thereto, of passing, for all purposes, through a certain road having no terminus upon the premises was not one which inhered in the land conveyed, did not concern the premises conveyed or the mode of occupying them, and, therefore, did not pass to a subsequent assignee of the land. The gist of the decision, however, seems to be that the court thought the true construction of the granted right was to use the road for purposes unconnected with the enjoyment or use of the land and that such a right would not pass to an assignee of the land "and appurtenances." The court said: "If a way is granted in gross it is personal only and cannot be assigned.... so common in gross sans nombre may be granted but cannot be granted over." Obviously, the quoted rule, if it were a rule, related to a mere easement of way or of passage which was not appurtenant to land and in which there was no investment-the type of right which might well have.been regarded as a mere license at that time.

The so-called rule of the Ackroyd case, if it were followed at all, should have been limited in its application to easements or privileges of passage, but the textbook writers and the courts, by dicta, in general referred simply to easements in gross. As a result, instead of strictly limiting the application of the so-called rule to easements of way or passage which were not appurtenant and renouncing it in other types of cases and especially in those in which the parties creating the easement obviously intended that it should be assignable and not personal, the courts, generally, have stated the alleged rule as a dictum, and then avoided it. So has confusion grown.

It appears that the reason for the original pronouncement was that the privilege granted (an easement of passage) was of the type which was ordinarily a mere license and that no fraud or serious deprivation of right would result if assignment were not permitted. Further, it was the type of easement which, if it could be assigned in severalty, or if it could be inherited, would lead to the possibility of a greatly expanded number of people who would be entitled to use the easement. In the absence of recording statutes, of an accurate description of the way, of the way being appurtenant to land, and of any investment in the easement, it can readily

4 1o C.B. I64, ro Eng. Rul. Cas. I (1850). 
be seen that the early-day courts might not wish to encourage the continuous existence of such an easement. However, under present-day conditions, it is obvious that there is no good reason why all easements in gross should not be held to be assignable, if such were the intention of the parties.

The trend of modern law has been toward the encouragement of the encumbering of the fee title, as illustrated by the increased use of building restrictions and zoning laws, and the recognition of many and varied rights reserved or granted in lands, such as mineral reservations, oil and gas leases, etc. With our modern recording acts, with their doctrine of constructive notice, it is practicable to permit the imposition of all sorts of encumbrances on realty, which, in the absence of such acts, would have been a source of confusion and inconvenience. Furthermore, the constant trend in modern law in the construction of written instruments or the interpretation of contractual arrangements has been to carry out the intention of the parties. In addition, it may be said that an easement in gross is ordinarily a present interest in land such as we normally expect to be assignable, and there appear to be no reasons of public policy to prevent the grantor's intention from being carried out by making such an interest freely alienable.

Despite the confusion which the repeated assertion of the alleged rule has created, an examination of the cases does not support the rule as announced by the textbook writers. Although there are many dicta, the only American cases which the writer has been able to find which can be said to support the rule are the ones given in the appended footnote..$^{5}$ Other cases which are sometimes cited in support of the alleged rule are found to be cases decided on the intention of the parties to convey a mere personal and, therefore, nonassignable right. ${ }^{6}$

5 Boatman v. Lasley, 23 Oh. St. 614 (I873) (private way); Garrison v. Rudd, I9 Ill. 558 (I858) (private way); Waller v. Hildebrecht, 295 Ill. II6, I28 N.E. 807 (I920) (alley for which no real necessity); Stockdale v. Yerden, 220 Mich. 444, I90 N.W. 225 (I922) (private way of which no formal assignment to plaintifi); Metzger \& Co. v. Holwick, I7 Oh. C.C. 605,6 Ohio C. D. 794 (1895) (driveway for which no real nécessity); Fisher v. Fair, 34 S.C. 203, I3 S.E. 470 (I89I) (private alley for which no real necessity); Safety BIdg. \& Loan Co. v. Lyles, I3I S.C. 542, I28 S.E. 724 (I925) (driveway for which no real necessity); Steele v. Williams, 204 S.C. 124, 28 S.E. 2 d 644 (I944) (private alley for which no real necessity).

6 By proper construction of the language of the instrument, Hall v. Armstrong, 53 Conn. 554, 4 Atl. II3 (I886); Mallet v. McCord, I27 Ga. 76I, 56 S.E. Ior 5 (1907); Koelle v. Knecht, 99 Ill. 396 (I88I); Wadsworth v. Smith, Ir Me. 278, 26 Am. Dec. 525 (I834); Ross v. McGee, 98 Md. 389, 56 Att. II 28 (1904); Wilder v. Wheeler, 60 N.H. 35I (1880); Schultz v. Carter, I53 Va. 730, I5I S.E. I30 (I930); or by looking "to the circumstances attending the transaction, the situation of the parties, the state of the thing to be granted and the object to be attained, to ascertain and give effect to the intention of the parties," Waller v. Hildebrecht, 295 III. II6, I 28 N.E. 807 ( I.920). 
All of the cases which are listed in the appended footnote, in support of the rule, relate to mere easements of way or passage. In all other American cases which the writer has found (aside from dicta or those which were decided on other grounds) the courts have either flatly refused to adopt the alleged rule or have found other ways to circumvent its application. Some courts have had the courage flatly to reject the alleged rule and to hold that an easement in gross as such is capable of assignment. Thus Massachusetts, in Goodrich v. Burbank, ${ }^{7}$ held a vendor of land may reserve to himself, "his heirs and assigns," the right of taking water forever from a spring situated on the land through a pipe of definite dimensions and that such right need not be annexed to any particular estate. Wisconsin expressed itself forcibly in Poull v. Mockley, ${ }^{8}$ which involved a conveyance to the grantee, "his heirs and assigns forever," of the right to take water from a well on the grantor's premises, stating: "We cannot see any substantial reason for holding that an easement in gross cannot be assigned or transferred, especially when the language of the grant shows unmistakably that the intention was that it should be enjoyed by the grantee, 'his heirs and assigns.'"

New York, in holding a right of way for a railroad an easement in gross which is transferable and inheritable like an estate in lands in Atlantic Mills v. New York Cent. R. Co., ${ }^{9}$ said:

The distinction oftimes made in the cases between a fee and an easement is based upon the use of those terms as indicating the uses to which the land or right of way may be devoted. A fee in this sense signifies the land itself, and the sum of all the uses to which the land may be devoted, while an easement or incorporeal heriditament is confined to a limited use. Nevertheless, in so far as duration of estates is concerned, an easement, or right in gross may be perpetual and inheritable, and transferable as a fee in lands. ${ }^{\mathrm{x}}$

In a recent New York case, Antonopulos v. Postal Telegraph Cable Co., II the court, in upholding the assignability of an easement in gross for a telegraph pole line, limited by the grant to seven poles, refused to hold that the grant conveyed an easement by implication for twenty-nine additional poles, saying:

7 I2 Allen (Mass.) 459, 90 Am. Dec. I6I (I866), followed in Amidon v. Harris, II3 Mass. 59 (1873).

${ }^{8} 33$ Wis. 482 (1873), followed in Pinkum v. Eau Claire, 8I Wis. 30I, $5 \mathrm{I}$ N.W. 550 (I892), with respect to an easement for a canal or raceway and a highway.

9 I 26 Misc. 349, 214 N.Y. Supp. I23 (I926).

ro Citing Miner v. New York Central \& H. R.R. Co., I23 N.Y. 242, 25 N.E. 339 (I890).

2x 26r App. Div. 564, 26 N.Y.S. 2d 403 (194r). 
It is difficult to conceive of a just basis for added rights by implication. This is especially so when it is recalled that at one time an easement in gross was so narrowly construed and was deemed so personal to the grantee that it was not assignable. 1... . Later, although courts do not favor by construction an easement in gross .... it was recognized as transferable and inheritable.

In general, however, the influence of the alleged rule was such that the courts felt obligated to give it lip service, after which they proceeded to negative or circumvent its application in numerous ways:

I. By giving effect to the evident intention of the parties that the easement in gross should be assignable. ${ }^{12}$

2. By saying a grant to one "his heirs and assigns" must be interpreted to mean just what it says and that the law will recognize no difference in their legal incidents, as affecting the burdened property, between easements appurtenant, incorporeal interests or estates in land in the nature of easements but subordinate to the fee, or mere servitudes. ${ }^{13}$

3. By establishing almost universally the rule that an easement will never be held or presumed to be in gross if it can fairly be construed to be appurtenant. $^{\text {I4 }}$ This rule has been implemented by the adoption, in a majority of jurisdictions, of the rule that a right of way may be appurtenant to land although the servient tenement is not adjacent to the domi-

12 Miller v. Lutheran Conference \& Camp Ass'n, 33I Pa. 24r, 200 Atl. 646 (1938). On this subject, the court stated: "In regard to easements in gross generally, there has been much controversy in the courts and by textbook writers and law students as to whether they have the attribute of assignability. There are dicta in Pennsylvania that they are non-assignable. Tinicum Fishing Co.v. Carter, . . . ; ; Lindenmuth v. Safe Harbor Water Power Corporation, 309 Pa. 58, 63, 64, I63 A. I59, 89 ACR II80; Commonwealth v. Zimmerman, 56 Pa. Super. 3 II, 3I5, 3I6. But there is forcible expression and even definite authority to the contrary. Tide Water Pipe Co. v. Bell, 280 Pa. I04, II2, II3, I24 A. 35I, 40 ALR 15I6; Dalton Street Railway Co. v. Scranton, $326 \mathrm{~Pa}$. 6, I2, I9I A. 133. Learned articles upon the subject are to be found in 32 Yale Law Journal 8I $3 ; 38$ Yale Law Journal I39; 22 Michigan Law Review 521; 40 Dickinson Law Review 46. There does not seem to be any reason why the law should prohibit the assignment of an easement in gross if the parties to its creation evidence their intention to make it assignable. Here, as in Tide Water Pipe Company v. Bell, the rights of fishing and boating were conveyed to the grantee-in this case Frank C. Miller-'his heirs and assigns,' thus showing that the grantor, the Pocono Spring Water Ice Company, intended to attach the attribute of assignability to the privileges granted."

${ }^{23}$ Tide Water Pipe Co. v. Bell, 280 Pa. I04, I24 Atl. 35 I (1924).

${ }^{4}$ Louisville and Nashville R.R. Co. v. Koelle, I04 Ill. 455 (I882); Kuecken v. Voltz, IIo Ill. 264 (1884); Whittaker v. Harding, 256 Ill. I48, 99 N.E. 945 (I9I2); Goldstein v. Raskin, 27 I Ill. 249, III N.E. 9 I (IgI6); Gulick v. Hamilton, 287 Ill. 367 , I22 N.E. 537 (IgIg); Jones v. Stevens, 276 Mass. 3I8, I77 N.E. 9I, 76 ALR 59I (I93I); Akers v. Baril, 300 Mich. 6I9, 2 N.W. $2 d$ d9I (I942); Collins v. Stewart, 302 Mich. I, 4. NW. $2 d 446$ (r942); Wilson v. Ford, 209 N.Y. I86, Io2 N.E. 6I4 (I913); Atlantic Mills v. New York Central R. Co., 22I App. Div. 386, 223 N.Y. Supp. 206 (x927); Weigold v. Bates, I44 Misc. 395, 258 N.Y. Supp. 695 (r932); Lindenmuth v. Safe Harbor Water Power Corp., 309 Pa. 58, I63 Atl. I59 (I932). 
nant tenement. ${ }^{25}$ Further, this rule has been extended in its scope by suggesting or declaring that when expenditures are made for a work which the easement is designed to serve, the easement is appurtenant to the work. ${ }^{\mathrm{x}}$

4. By the recognition of the assignability of profits a prendre ${ }^{\text {I7 }}$ and then holding the easement to be either a profit a prendre or in the nature of a profit a prendre. ${ }^{\mathbf{8}}$

5. By excepting water rights in gross and rights of way for ditches. ${ }^{19}$

6. By declaring the easement to be an interest or estate in land (as distinguished 'from an incorporeal right) because permanent structures were installed in or erected upon the land. ${ }^{20}$

7. By distinguishing between easements designed for commercial exploitation and easements for personal enjoyment. ${ }^{2 x}$

8. By declaring that of necessity the attributes of nonassignability do not inhere in rights of way granted to public service corporations..$^{22}$

9. By declaring that state statutes which provide that every species of property, except a mere possibility not coupled with any interest, may be transferred, make such rights assignable unless they are expressly or by necessary implication made personal to a particular individual. ${ }^{23}$

Io. By holding applicable to easements state statutes which declare conveyances of real estate to be in fee, even though words of inheritance

Is See annotation: "May right of way be appurtenant where the servient tenement is not adjacent to the dominant." 76 ALR 597 (I932).

${ }^{6}$ Lindenmuth v. Safe Harbor Water Power Corp. 309 Pa. 58, I63 Atl. ${ }_{59}$ (1932); Sweetland v. Grants Pass New Water, Light \& Power Co., 46 Ore. 85, 79 Pac. 337 (Ig05).

17 Profits a prendre in gross are universally held to be inheritable or assignable (if granted in fee), even though not admeasurable, on the basis that such rights are interests in land. See Amer. \& Eng. Encyclopaedia of Law vol. Io, p. 403 (2d ed., I899); note in 32 Yale I. J. 813 (I923); I9 Corpus Juris $\S$ II, and cases cited therein under note 25 .

${ }^{18}$ See Cross v. Berlin Mills Co., 79 N.H. II6, I05 Atl. 4II (I9I8); Davis v. Briggs, II7 Me. 536 , 105 Atl. 128 (Igr8).

19 Osnes Livestock Co. v. Warren, I03 Mont. 284, 62 P. 2 d 206 (1936); Patterson v. Chambers Power Co., 8I Ore. 328, I59 Pac. 568 (I916).

${ }^{20}$ Standard Oil Co. v. Buchi, 72 N.J. Eq. 492, 66 Atl. 427 (1907); Cross v. Berlin Mills Co. 79 N.H. II6, I05 Atl. $41 \pm$ (I9I8); Cumberland Pipe Line Co. v. Lewis, I7 F. 2d I67 (D.C.E.D. Ky., 1926).

2x See Miller v. Lutheran Conference \& Camp Ass'n, 331 Pa. 24r, 200 Atl. 646 (1938).

${ }_{22}$ Ocean Shore R. Co. v. Spring Valley Water Co., 87 Cal. App. I88, 262 Pac. 53 (Ig27).

${ }^{23}$ Fudickar v. East Riverside Irr. Dist., rog Cal. 29, 4I Pac. I024 (1895); Callahan v. Martin, 3 Cal. (2d) I10, 43 P. $2 d 788$ (1935). 
are not used unless a lesser estate is specifically provided for in the instrument. ${ }^{24}$

With respect to the Illinois view, it will be noted that two Illinois cases, Garrison v. Rudd ${ }^{25}$ and Waller v. Hildebrecht ${ }^{26}$ which involved easements of way or passage, upheld the alleged rule that an easement in gross is personal and not assignable. A reading of the last-mentioned case discloses that it was difficult to ascertain the intention of the parties as to assignability. However, accepting both cases as authority for the rule in Illinois, it is interesting to see how the effect of its adoption has been eliminated by other cases. Thus the Illinois courts have held that an easement will not be presumed to be in gross if it can fairly be construed to be appurtenant. ${ }^{27}$ Further limiting the possible application of the alleged rule, Illinois has adopted the rule supported by the weight of authority that a right of way may be appurtenant to land even though the servient tenement is not adjacent to the dominant. And in Goodrevillie Co.v.Commonwealth Electric Co. ${ }^{28}$ it was held that not only is it not necessary that the dominant and servient estates be contiguous, but it is not necessary that the right of way should terminate on the dominant estate. The case just cited has practically insured the interpretation of an easement as assignable, if the parties so intended, by holding applicable to easements the Illinois statute which provides that "every estate in lands which shall be granted, conveyed or devised although other words heretofore necessary to transfer an estate of inheritance be not added, shall be deemed a fee simple estate of inheritance if a less estate be not limited by express words." ${ }^{29}$

Michigan, which also adopted the alleged rule that an easement in gross is personal and not assignable in a case involving an easement of way or passage, likewise limited the possible application by adopting the rule, in Collins v. Stewart,,$^{30}$ that an easement will not be held to be in gross if it can fairly be construed to be appurtenant, and has sustained that rule

\footnotetext{
${ }_{24}^{4}$ Salem Capital Flour Mills Co. v. Stayton Water-Ditch \& Canal Co., 33 Fed. I46 (C.C. Ore., I887); Goodwillie Co. v. Commonwealth Electric Co., 24I Ill. 42, 89 N.E. 272 (1909).

${ }^{25}$ Ig IIl. 558 ( 1858 ).

${ }^{26} 295$ Ill. II6, I 28 N.E. 807 (1920).

${ }^{27}$ Louisville and Nashville R.R. Co. v. Koelle, I04 Ill. 455 (I882); Kuecken v. Voltz, I IO Ill. 264 (I884); Whittaker v. Harding, 256 III. $\mathrm{r}_{48}, 99$ N.E. 945 (I9I 2); Goldstein et al v. Raskin et al., 27 I Ill. 249, III N.E. 9I (IgI6); Gulick v. Hamilton, 287 Ill. 367, I22 N.E. 537 (I9I9).

${ }_{28} 24$ x Ill. $42,74,89$ N.E. 272 (I909).

${ }^{29}$ Smith-Hurd Ann. Stat. (perm. ed.), ch. 30, § 12.

${ }^{30} 302$ Mich. r, 4 N.W. 2d 446 (I942).
} 
notwithstanding the silence of the deed as to the lands to which the easement might be appurtenant. ${ }^{3 x}$

Among the cases which have been cited as upholding the alleged rule are three easement-of-way or passage cases from South Carolina. However, it should be pointed out that in those cases the court stated that the right of way was not reasonably or essentially necessary to the enjoyment of the premises, and that the rule in South Carolina is that for a right of way to be appurtenant and to inhere in the land it must be necessary to the enjoyment of the land. Consequently, easements which would elsewhere be held to be appurtenant must be held in South Carolina to be in gross, if they are not essentially necessary to the enjoyment of the land.

It is apparent from what has been said that there is very little support for the alleged rule, and what support there is, is confined to mere easements of way or passage. Furthermore, it will be noted that with the exception of a recent South Carolina case, decided under the unusual rule of that state, the cases are fairly old and some of them are of very ancient vintage. Arrayed against this weak and confined support for the alleged rule are a considerable number of cases holding that an easement without a dominant tenement may be created in perpetuity and may be, by its terms, or by the intention of the parties, made assignable. These cases cover a wide variety of types of easement. ${ }^{32}$ Such being the state of the law, it is high time for the courts and textbook writers to end the confusion over the assignability of easements.

There is not now, and there has not been for a long time, any valid reason whatsoever why a distinction should be drawn between easements in

${ }^{3 x}$ In Akers v. Baril, 300 Mich. 6I9, 2 N.W. 2d 79I (1942).

${ }^{32}$ Railroad right of way: Ocean Shore R. Co. v. Spring Valley Water Co., 87 Cal. App. I88, 262 Pac. 53 (1927); Atlantic Mills v. New York Central R. Co., 126 Misc. Rep. 349, 2I4 N.Y. Supp. I23 (I926).

(1937).

Water pipe line right of way: Goodrich v. Burbank, I2 Allen (Mass.) 459, $90 \mathrm{Am}$. Dec. I6I (I886); Amidon v. Harris, II3 Mass. 59 (I873). (1892).

Canal and highway right of way: Pinkum v. City of Eau Claire, 8I Wis. 30r, 5 I N.W. $55^{\circ}$

Mill race right of way: Patterson v. Chambers Power Co., 8I Ore. 328, 159 Pac. 568 (I9I6).

Right of way for booms in river: Cross v. Berlin Mills Co., 79 N.H. 116, 105 Atl. 4 Ir (I918). Oil pipe line right of way: Standard Oil Co. v. Buchi, 72 N.J. Eq. 492, 66 Atl. 427 (rgo7).

Oil pipe line and telegraph and telephone lines: Tide Water Pipe Co. v. Bell, 280 Pa. I04, I24 Atl. 35 I (I924).

Telegraph line right of way: Antonopulos v. Postal Telegraph Cable Co., 26r App. Div. 564,26 N.Y. Supp. 2d 403 (I94I).

Power line right of way: Sweetland v. Grants Pass New Water, Light \& Power Co., ${ }_{4} 6$ Ore. 85, 79 Pac. 337 (1905). 
gross and easements appurtenant with reference to assignability or inheritability. As stated previously, it is understandable that the early-day courts, in the absence of public records, should have been loath to encourage the continuous existence of easements of way or passage which were not appurtenant to land. Such easements, being unconnected with the use or enjoyment of land, were not of a nature to place a subsequent purchaser of the servient tenement upon notice; and, if they were assignable or inheritable, there was no way in which the owner of the servient tenement could readily ascertain what persons were entitled to the enjoyment of the easement. ${ }^{33}$ However, since the advent of recording statutes and probate court records, any objections based upon lack of notice or indefiniteness have been swept away. It is common practice to record instruments conveying permanent rights in land. In the absence of such recording, the subsequent purchaser, without actual notice, is not bound if the easement is not open and visible, so as to constitute notice. Under such circumstances, we should cease attempting to make distinctions with reference to the assignability or inheritability of easements based on whether we determine them to be in gross or appurtenant.

From a practical standpoint, it is perfectly obvious that, whether a burden on land is called an easement in gross or an easement appurtenant, the two things are of the same nature, and influence the property in exactly the same way. Consequently, we should, in keeping with the trend of modern law, be honest with ourselves and the future. We should frankly say of these two types of easements: "The law will recognize no difference in their legal incidents, as affecting .... property, merely because they have different names." 34 Then we can freely apply the true rule of construction-the intention of the parties.

33 Profits a prendre, although burdens of a very similar nature and subject to the same criticisms, have been universally held to be inheritable or assignable (if granted in fee). See note 17 , supra.

34 Tide Water Pipe Co. v. Bell, 280 Pa. I04. I 24 Atl. 35I (I924). 